\title{
Economic Impacts of COVID-19 on Microfinance Institutions and Small Businesses: Empirical Survey from Somalia
}

\author{
Nor Abdulle Afrah \\ nuur@bu.edu.so \\ Senior lecturer and Research Fellow, Faculty of Economics and Management, Benadir University
}

\author{
Abdullahi Mire Mohamed \\ Abdullahimire@bu.edu.so \\ Senior lecturer, Faculty of Economics and Management, Benadir University
}

\begin{abstract}
The microfinance institutions promote the entrepreneurial innovations that contribute the fundamentals of a healthy economy and job creation opportunities. In Somalia, the small businesses have ever been valuable resources to encourage the economic sustainability of Somali country. After the destruction in January 26, in 1991, the people of Somalia have relied on the entrepreneurial skills to develop small businesses on which the lives of many Somali people have hinged. Therefore, this study assesses the economic impacts of covid-19 on microfinance institutions and small businesses. The study follows descriptive correlation. The overall sample consisted of 40 participants in Benadir region. The study found that covid-19 has negative impact on both microfinance institutions and small businesses as shown by the mean index of microfinance institutions $\mathbf{1 . 7 2}$ and standard deviation $\mathbf{0 . 4 8}$, likewise, the mean index of small businesses scored 1.86 and standard deviation 0.69 .
\end{abstract}

Key words: Economic impacts, Covid -19, Microfinance Institutions, Small Businesses, Benadir region

DOI: $10.7176 / \mathrm{EJBM} / 13-6-21$

Publication date:March $31^{\text {st }} 2021$

\section{Introduction}

In recent decades, there have been new several diseases that have emerged in different geographical zones, with pathogens including Ebola virus, Zika virus, coronaviruses and Nipah virus. Lately, coronaviruses have been associated with significant disease outbreaks in East Asia and the Middle East. The severe acute respiratory syndrome and the Middle East respiratory syndrome began to emerge in 2002 and 2012, respectively. Recently, a novel coronavirus, severe acute respiratory syndrome coronavirus (SARS-CoV-2), causing coronavirus disease 2019 (COVID-19), emerged in late 2019, and it has posed a global health threat and economic recession, causing an ongoing pandemic in many countries and territories all around the world. (Sharun, Kuldeep, \& Shubhankar, 2020)

Coronavirus is a pandemic infectious disease that influences the economy direct and indirect economic costs of illness are often the subject of the health economics studies on the burden of disease. The conventional approach uses information on deaths (mortality) and illness that prevents work (morbidity) to estimate the loss of future income due to death and disability. Losses of time and income by carers and direct expenditure on medical care and supporting services are added to obtain the estimate of the economic costs associated with the disease. This conventional approach underestimates the true economic costs of infectious diseases of epidemic proportions which are highly transmissible and for which there is no vaccine (e.g. HIV/AIDS, SARS and pandemic influenza). The experience from these previous disease outbreaks provides valuable information on how to think about the implications of COVID-19 (Warwick \& Roshen, 2020)

Covid-19 created immense social and economic problems at all levels, including social phobia, unemployment, supply chain disruption, stock market crashes, economic lockdown, and de-globalization. Due to the uniqueness 
of the Covid-19 crisis which is a sudden and unexpected event that threatens to disrupt an organization's operations and poses both a financial and a reputational threat" (Coombs, 2007:163). Early work on crisis management indicates that a sudden and unexpected event threatens business goals and exert stress on management to take prompt action to respond (Hermann 1963).

At the end of 2019, a series of pneumonia cases of unknown cause emerged in Wuhan (Hubei, China). A few weeks later, in January 2020, deep sequencing analysis from lower respiratory tract samples identified a novel virus severe acute respiratory syndrome coronavirus 2 (SARS-CoV-2) as causative agent for that observed pneumonia cluster. On February 11th, 2020, the World Health Organization (WHO) Director-General, Dr. Tedros Adhanom Ghebreyesus, named the disease caused by the SARS-CoV-2 as "COVID-19", and by March 11th, 2020 when the number of countries involved was 114 , with more than 118,000 cases and over 4000 deaths, the WHO declared the pandemic status . Corona Virus Disease 2019 (COVID-19) is an RNA virus, with a typical crownlike appearance under an electron microscope due to the presence of glycoprotein spikes on its envelope. It is not the first time that a coronavirus causing an epidemic has been a significant global health threat: in November 2019, an outbreak of coronaviruses (CoVs) with severe acute respiratory syndrome (SARS)-CoV started in the Chinese province of Guangdong and again, in September 2012 the Middle East respiratory syndrome (MERS)-Co V appeared. There are four genera of CoVs: (I) $\alpha$-coronavirus (alphaCoV), (II) $\beta$-coronavirus (betaCoV) probably present in bats and rodents, while (III) $\delta$-coronavirus (deltaCoV), and (IV) $\gamma$-coronavirus (gammaCoV) probably represent avian species. (Gennaro, et al., 2020)

\section{ECONOMIC IMPACTS OF COVID -19 ON MICROFINANCE INSTITUTIONS}

Microfinance is no stranger to crisis, but the COVID-19 is different. Unlike previous downturns which originated from financial markets, the current crisis is spread through an invisible virus which is difficult to contain and control. The virus not only negatively affects businesses and commerce, it also kills people in numbers unseen for a century. It creates social disruption and changes the way we live and work. COVID-19 is a disease caused by a new type of coronavirus (SARS-CoV-2). First identified in China in December 2019 in the Chinese municipality of Wuhan, it quickly spread to other regions of China and the world. (Kinga, Piotr , \& Justyna , 2020)

Transmission of corona virus has had not only health impact through infection all over the world, but also serious economic impact because of lockdown measures adopted to contain its spread in the community and increasing health expenses. Closure of almost all economic activities following the lockdown measure has seriously affected people and various institutions. Among others, microfinance financial institutions (MFI) have also been adversely impacted. Lockdown measures and prohibition of gathering of people in mass because of fear of transmission of the disease hampered the operation of MFIs' activities in the field. Moreover, closure of many economic activities, except a few essential businesses, damaged the earnings of borrowers of MFIs, thereby loan recovery. (Shrestha, 2020)

The battle against corona does not confine to only economic resurgence by supplying microcredit to the poor clients in both demand and supply sides of microfinance sector but how to protect them from the offense of the corona in the health perspectives. In other words, imperatively it is warranted that the survival of human beings in the pandemic in the Microfinance sector merits attention on priority in the revival package. It is therefore surmised that in the process of ushering in a new social order with a resilient ecology in the Microfinance sector, there is a dilemma in awarding priority either for economic revival through the flow of microcredit for releasing financial stress or human survival with the resilient physical capability in the process of recovery from the pandemic. ( Alshebami \& Dr. V., 2020)

Presently, the whole world is suffering from the so-called COVID-19 pandemic that has almost paralyzed the entire world and heavily affected the poor segment of it. Poor people are affiliated often to the microfinance sector that had a combined portfolio of about $\$ 124$ billion in outstanding loans and about $\$ 80$ billion in saving (Greta Bull, 2020). There are about 139.9 million individual borrowers who have received supports from the services of MFIs compared to merely 98 million who received similar benefits in 2009. Of these 139.9 million borrowers, $80 \%$ are women and $65 \%$ are rural borrowers (Microfinance Barometer, 2019). The poor people have been largely affected by this pandemic because its impact has gone beyond their immediate health needs and it has prevented them from meeting their most necessities and lead to more acute on the economic well-being (Beinker, 2020). This reminds us of the West Africa Ebola crises that took place in the year 2014 which had an economic impact of more than $\$ 2.8$ billion as per the estimates of the World Bank (Abed et al, 2017). 


\section{ECONOMIC IMPACTS OF COVID -19 ON SMALL BUSINESS}

Small businesses are vulnerable to crisis, however little is still known about how they cope during long crisis as the COVID-19 pandemic. It was found that the sudden decline in demand has the strongest impact on small businesses. As compared with large businesses, new startups and small businesses show high exibility in their reactions to the crisis, partly due to the low level of bureaucracy and limited social responsibility compliance. Among the various types of response strategies, all participants adopted flexible HR strategies. Other common survival strategies include the increase of product diversification, exploration of new markets, and increase of learning. Some of the small businesses had a formal crisis plan and strategy before the outbreak, and these firms tend to have longer history, experience in dealing with crisis, and operate in more regulated sectors. At the firm level, the core of crisis management is to develop strategies that minimize economic loss and increase resilience through a crisis event. Existing literature on crisis management mostly targets large firms with less attention on small and medium size enterprises (Herbane, 2013). Small firms, due to resource constraints, weaker market positioning, and other factors, may be more vulnerable to crisis events. (ALVES, Cheng, LUO, \& HAO, 2020)

Social distancing restrictions and demand shifts from COVID-19 are expected to shutter many small businesses, but there is very little early evidence on impacts. The drop in business owners was the largest on record, and losses were felt across the world nearly all industries and even for incorporated businesses. Although the effects of COVID-19 on the economy showed up quickly in the stock market, yet, the real estate market and unemployment claims, the effects of coronavirus on small business are not well known because of the lack of timely businesslevel data. (Fairlie, 2020)

Small businesses are likely to be severely affected, as they tend to be more concentrated in sectors that have been directly affected by COVID-19 response measures (e.g. retail and services) and are typically more credit constrained than larger businesses (Cao and Leung, 2020; Kumar and Francisco, 2005). Importantly, small businesses make up the majority of companies in Somalia and are responsible for a substantial fraction of employment. The expectation of small business owners about the future of their businesses remains uncertain and in general negative it was deteriorating day after day. (Humphries, Christopher, \& , 2020 )

The year 2020 has been incredibly challenging for the global community. The spread of the novel coronavirus, known as COVID-19, has led to an unparalleled health crisis in countries across the world. The crisis has had unprecedented and serious impacts on all aspects of how people communicate, work, produce, trade, consume and live. The economic ramifications of the pandemic quickly became apparent, and small and medium sized enterprises (SMEs) have been on the front lines. With workers and customers staying indoors, and supply chains tested by shutdowns, the small companies that provide $70 \%$ of jobs in countries around the world and about half of economic activity have been put under stress (Tembo, 2020). Small companies tend to be vulnerable during an economic crisis, in part because they have fewer resources with which to adapt to a changing context.

\section{Methodology}

The main objective of the study was to evaluate the Economic impacts of covid 19 on microfinance institutions and Small businesses in Mogadishu, Somalia. The data was collected through telephone interview and questionnaires that were sent through Email for the target respondents with regard to the movement restrictions imposed by the government to decrease the spread of covid-19. The questionnaire consisted of the variables of the study which are microfinance institutions (independent variable) and small businesses (dependent variable). The respondents who contributed the study were 40 participants with relevant information on microfinance institutions and small businesses. Using Morgan and Krejcie sample size determination (1970), the target population is 45 and the sample size is 40 .

\section{Data Presentation and Analysis}

The main objective of the study was to identify the Economic Impacts of Covid 19 on Microfinance Institutions and Small Businesses in Benadir region. The data of the study was collected using a researcher devised questionnaire scored on response mode ranging from $1=$ agree, $2=$ strongly agree, $3=$ disagree, and $4=$ strongly disagree for each of these study variables and the findings are presented below. 
As shown table above questions were divided into two parts, first part was about Economic Impacts of Covid 19 on Microfinance Institutions; and second part Economic Impacts of Covid 19 on Small Businesses. First part was independent variable which consisted of six questions. First question concerns the Increase in portfolio at risk, financial institutions make portfolio investments hoping to gain profit but owing to the pandemic covid-19, the risk of portfolio investments was high as the mean scored $\mathbf{1 . 0 2 5 0}$ and standard deviation .15811. The second question was lack of financial liquidity, this shows if there is no return from those invested by the microfinance institutions, the financial liquidity of microfinance institutions may decrease and it may result in lack of financial liquidity as the mean is high $\mathbf{1 . 1 2 5 0}$ and standard deviation .33493.. Question three describes Customer behavior change, this illustrates if the customer fails to repay the loan on its due date because of the market economic crisis caused by coronavirus. This may contribute the lack of financial liquidity of microfinance institutions in Benadir Region as the mean is high $\mathbf{1 . 4 0 0 0}$ and standard deviation .54538. Question four was saving withdrawals by clients became larger than usual, as the lockdown increased, some of the clients have begun to withdraw their deposits form the banks and this became another worry that faced the microfinance institutions as the mean is high $\mathbf{1 . 8 0 0 0}$ and standard deviation $\mathbf{. 5 6 3 8 7}$. Question five explains that overdue payment increased and this may induce lack of financial circulation as the mean scored very high $\mathbf{2 . 3 0 0 0}$ and $\mathbf{. 5 6 3 8 7}$...Question six was that business uncertain to recover, this has become an important question of which answer became an obstacle but most of the respondents agreed that business recovery depends on the prevention of covid-19 as the mean scored very high $\mathbf{2 . 6 7 5 0}$ and standard deviation $\mathbf{. 6 9 3 8 4}$

Table 1: Means and standard deviation results of economic impacts of covid 19 on microfinance institutions in Benadir region $(\mathrm{N}=40)$

\begin{tabular}{|l|l|l|l|}
\hline $\begin{array}{l}\text { Indicators of Economic impacts of covid 19 on microfinance } \\
\text { institutions }\end{array}$ & Mean & $\begin{array}{l}\text { Standard } \\
\text { deviation }\end{array}$ & Interpretation \\
\hline Increase in portfolio at risk & 1.0250 & .15811 & High \\
\hline Lack of financial liquidity & 1.1250 & .33493 & High \\
\hline Customer behavior change & 1.4000 & .54538 & High \\
\hline Saving withdrawals by clients became larger than usual & 1.8000 & .56387 & High \\
\hline Overdue payment increased & 2.3000 & .56387 & Very High \\
\hline Business uncertain to recover & 2.6750 & .69384 & Very High \\
\hline Mean index & $\mathbf{1 . 7 2}$ & $\mathbf{0 . 4 8}$ & High \\
\hline
\end{tabular}

Source: Primary Data

Second part was small business (dependent variable) it consisted of six questions as follow. First question was shortage of cash flow of which result became agrees by mean $\mathbf{1 . 1 5 0 0}$ and standard deviation of $\mathbf{. 4 8 3 0 5}$. Question two asked to the respondents if there was increased stress and worry of small business owners became agree as the pandemic coronavirus made the low income workers stress and worry according to the mean $\mathbf{2 . 2 0 0 0}$ and standard deviation .98819. Question three was reduction of revenue used to be generated by small businesses and the response given was agree with mean $\mathbf{1 . 4 5 0 0}$ and standard deviation $\mathbf{. 5 9 8 6 1}$. Question four was salary deduction and some of the small businesses began salary deduction as the revenue of the small businesses decreased during the covid-19 and this was supported by the satisfaction of the respondents as the mean scored very high $\mathbf{1 . 7 2 5 0}$ and $\mathbf{. 5 9 8 6 1}$. Question five asked respondents if there were financial challenges, most of the respondents agreed the existence of financial challenges and the result turned into agree by mean $\mathbf{2 . 1 0 0 0}$ and standard deviation $\mathbf{. 7 0 8 9 2}$. Question six focused on the existence of strategic challenges that faced the small businesses and owing to the existence of financial challenge, there was strategic challenge because strategic implementation requires finance and there was revenue reduction during covid-19, in the light of this, the result turned into agree by mean 2.5750 and standard deviation $\mathbf{. 8 1 2 9 6 .}$ 
Table 2: Means and standard deviation results of economic impacts of covid 19 on small businesses in Benadir region $(\mathbf{N}=\mathbf{4 0})$

\begin{tabular}{|l|l|l|l|}
\hline $\begin{array}{l}\text { Indicators of Economic impacts of covid 19 on small } \\
\text { businesses }\end{array}$ & Mean & $\begin{array}{l}\text { Standard } \\
\text { deviation }\end{array}$ & Interpretation \\
\hline Shortage of cash flow & 1.1500 & .48305 & Very High \\
\hline Increased stress and worry of Small Business owners & 2.2000 & .98819 & High \\
\hline Reduction of Revenue & 1.4500 & .55238 & Very High \\
\hline Salary deduction & 1.7250 & .59861 & Very High \\
\hline Financial challenges & 2.1000 & .70892 & High \\
\hline Strategic challenges & 2.5750 & .81296 & High \\
\hline Mean index & $\mathbf{1 . 8 6}$ & $\mathbf{0 . 6 9}$ & Very High \\
\hline
\end{tabular}

Source: Primary Data

\section{Discussions and Conclusions}

The main objective of the study was, to investigate the economic impacts of covid-19 on microfinance institutions and small businesses. In the findings of research, the social distancing restrictions and demand shifts from COVID19 are likely to shutter many small businesses and entrepreneurial ventures owing to the economic downturn caused by the pandemic corona virus known as covid-19. The study found income losses, and future economic inequality that are associated with the lifecycle of the population in Benadir region. The research postulated that the economic and financial impacts flowing from lockdowns to control the spread of COVID-19 have been severe in most of Somali country, with substantial declines in the incomes of people at the base of the economy, many of whom rely on microfinance institutions to manage their households.

The last finding of literature was research conducted by (Prakash Kumar Shrestha, 2020), he studied the impact of Covid-19 on Microfinance Institutions of Nepal, his study found that the spread of pandemic has both health and economic effect in any country.. Assessment is done by evaluating the changes in some major financial indicator such as saving, loans, non-performing loans, profitability, change in the number of employees and borrowers among others after the imposition of lockdown measures by the Government to contain the spread of coronavirus. Downside risks still exist as shown by the growing number of overdue borrowers. Concrete, collaborative and innovative approaches are needed to navigate through this troubled times. In the conclusion, the covid-19 has negative impact on both microfinance institutions and small businesses as shown by the mean index of microfinance institutions $\mathbf{1 . 7 2}$ and standard deviation $\mathbf{0 . 4 8}$, likewise, the mean index of small businesses scored $\mathbf{1 . 8 6}$ and standard deviation $\mathbf{0 . 6 9}$.

\section{Reference}

Alshebami, A. S., \& D. R. (2020). AN IMPERATIVE NEED FOR A NEW SOCIAL ORDER IN MICROFINANCE COMMUNITY - TOWARDS USHERING IN A RESILIENT ECO-SYSTEM IN THE BATTLE AGAINST CORONA. International Journal of Research -GRANTHAALAYAH.

A. J., Cheng, L. T., L. Y., \& H. W. (2020). Crisis Management for Small Business during theCOVID-19 Outbreak: Survival, Resilience and Renewal Strategies of Firms in Macau.

Fairlie, R. (2020). The Impact of COVID-19 on Small Business Owners: Evidence of Early-Stage Losses from the April 2020 Current Population Survey.

Gennaro, F. D., D. P., C. M., M. A., V. R., N. V., \& L. S. (2020). Coronavirus Diseases (COVID-19) Current Status and Future Perspectives: A Narrative Review. International Journal of Environmental Research and Public Health.

Humphries, J. E., C. N., \& , G. U. (2020). THE EVOLVING IMPACTS OF COVID-19 ON SMALL BUSINESSES SINCE THE CARES ACT. 
K. D., P. K., \& J. P. (2020). Impact of COVID-19 Pandemic on theMicrofinance Sector in Europe: Field Analysis and Policy Recommendations.

S. K., K. D., \& S. S. (2020). Coronavirus Disease 2019-COVID-19. AMERICAN SOCIETY FOR MICROBIOOGY

Shrestha, P. K. (2020). Impact of Covid-19 on Microfinance Institutions of Nepal. Reserach Gate.

Tembo, D. (2020). COVID-19: The Great Lockdown and its Impact on Small Business, SME COMPETITIVENESS OUTLOOK.

W. M., \& R. F. (2020). The Global Macroeconomic Impacts of COVID-19:Seven Scenarios*. 